\title{
Simplicity and Beauty in Basheer's The Inheritors of Earth
}

\author{
Dr. Josit Mariya \\ Department of Communicative English \\ St. Thomas College \\ Palai, Kerala, India \\ jositmariya@gmail.com
}

Abstract

Vaikom Muhammed Basheer is a notable writer of Malayalam literature. His works are always close to nature. People can easily identify his works because of their lucid language and their inclination to nature. In his work, 'Bhoomiyude Avakashikal' (The Inheritors of Earth), the author tries to talk about the need of considering the animals and birds around us because they are also a part of our earth. Basheer sheds light on the truth that the entire species in this world have the same rights that man holds. Each and every living being has the equal right to live and enjoy their surroundings as human beings. If we don't protect our nature - the vegetation and biodiversity around us - we have no future.

Keywords: Nature, mutual co-existence, eco-system, Vasudhaiva Kudumbakam, Vaikom Muhammad Basheer

Abdul Rahman Muhammed Basheer, popularly known as Vaikom Muhammed Basheer, the well-known novelist and short story writer in Malayalam Literature was born in 1910 at Thalayolaparambu in Kerala, India. He is known for the use of language in his literary works. He mainly used an unconventional style of language. His literary style followed the language spoken by his villagers and he even did not care about the grammatical correctness of the sentences in his writings. He was an intelligent observer of human life so that he could skilfully combine humour and pathos in the lives of various characters in his 
works. His works are characterised by an idiosyncratic, path-breaking yet down-to-earth literary style.

He was so interested in Gandhian thought from his childhood and he also participated in Salt Satyagraha. Being an Indian independence activist, he had to spend a few years in prison. He travelled and lived in various places in India and abroad and these experiences became the base for various themes of his novels. He had plenty of experiences to write about. That's why it's no wonder that he himself became the protagonist in most of his writings. Most of the side kick characters in his works were either his own family members or the friends close to his surroundings. Nature and the creatures around him also had the same or more importance than the human counterparts in Basheer's writings. The experiences during his long travels and the conditions that existed in ours ociety formulated his writing style. The major characteristics of his works were the presence of philosophical content and the elements of social comment and commitment. Basheer beautifully portrayed the themes like Love, poverty as well as the rough realities of life.

All of Basheer's stories have found their way into the hearts of readers, and his novels were translated into many languages. Malayalee's addressed him as " Beypore Sulthan (The king of Beypore) ". His notable works include Pathummayude Aadu, Balyakalasakhi, Ntuppuppakkoranedarunnu, Mathilukal,Bhoomiyude Avakashikal, Premalekhanam etc. His humorous way of writing makes readers laugh and cry at the same time. His characters were underprivileged people. His fantasy world dealt with characters like prisoners, beggars, prostitutes, homosexuals, thieves etc. The 1977 Malayalam short story, 'Bhoomiyude Avakashikal' (The Inheritors of Earth), is written in a typical Basheer style with wisdom and humour. Basheer was an ardent adherent of Mahatma Gandhi, and he followed various ideologies of his role model throughout his life. He believed and practised the concepts of coexistence and non-violence and this was the leitmotif of this short story. Sometimes we feel 
the character of Basheer in this story eccentric, but his idea of nature and mutual co-existence is all-encompassing companionship and harmony.

The story, The Inheritors of Earth, states that Basheer owns a coconut orchard of two and a half acres and the government has given him the ownership document of the same. $\mathrm{He}$ says that he will be the sole owner of the land. He made fences around his land, but within a few days, he had to encounter some uninvited guests. Eventually, they started to live on his property, even without considering him -the landlord! These uninvited guests were none other than, the butterflies, centipedes, spiders, cockroaches, ants, termites, cobra etc. Selling the coconuts from this property was the main source of income for our writer and his family.

The problem starts when their coconuts were eaten by some unknown animals. Basheer's wife, Fabi first commented that it would be rats. She suggested that they need rat poison to kill the culprits. But the author was against this idea. Even though she arranged rat poison and put it in different places, that didn't solve the problem. Later they identify that the bats are the real culprits. Fabi decided to kill these trespassers at any cost. She and her cousin went on to kill the bats by using gun. But they were chased and stopped by some people claiming that bats are considered and revered as the souls of their forefathers.

Basheer questioning us:

Can man thrive without destroying any other living things? God has created billions of Microbes. Medicines kill them is it justice? A new ideology is needed. Is life possible without killing others?

Nothing in this world is useless and all the creature have their own role to maintain the balance of the ecosystem. In this story, Basheer shows us the right of trees, the rights of animals, the rights of birds and the rights of all living things. Basheer made a prophecy that 
man is the destroyer of the earth. We men destroyed our nature. Now human beings facing dangerous threats from Nature.

In this land, all living beings have the same rights. But man fragmented the lands and makes their territory leaving our ecosystem in danger. So these beings lost their land and they were out from their territory. Every being had rights on this land and we should live in harmony with them. Here the author is using the ancient Indian concept of "Vasudhaiva Kudumbakam". Vasudha means 'the earth' and Kutumbakam means ' family'. In other words, the whole world is a family. We should live in harmony without killing each other. 


\section{Bibliography}

Basheer, Vaikom Muhammad. Bhoomiyude Avakashikal, D.C. Books, Kottayam, 1977.

---, The Inheritors of Earth, D.C. Books, Kottayam, 1977. 